\title{
Stem-cell library boosts the case for change
}

\section{Erika Check, Washington}

A fertility clinic in Chicago, Illinois, has announced that it has created a large library of embryonic stem-cell lines - many of them carrying disease genes.

The announcement is significant, stemcell specialists say, because cell lines carrying disease genes are in short supply and could be useful for studying illnesses with a genetic component. The existence of a large number of such cell lines could increase pressure on President George Bush to change his stemcell policy, which prohibits federally funded scientists from working on them.

Yury Verlinsky, director of the Reproductive Genetics Institute in Chicago, revealed the existence of the lines at a meeting of the International Society for Stem Cell Research last week. His colleague, Anver Kuliev, says that the group, which has not yet published details, has derived "a few dozen" human embryonic stem-cell lines from normal patients. They have also derived about a dozen lines that carry mutated disease genes including those for $\beta$-thalassaemia, a condition characterized by defective blood cells, and various chromosomal abnormalities.

Kuliev says his group has become skilled at producing embryonic stem-cell lines, and

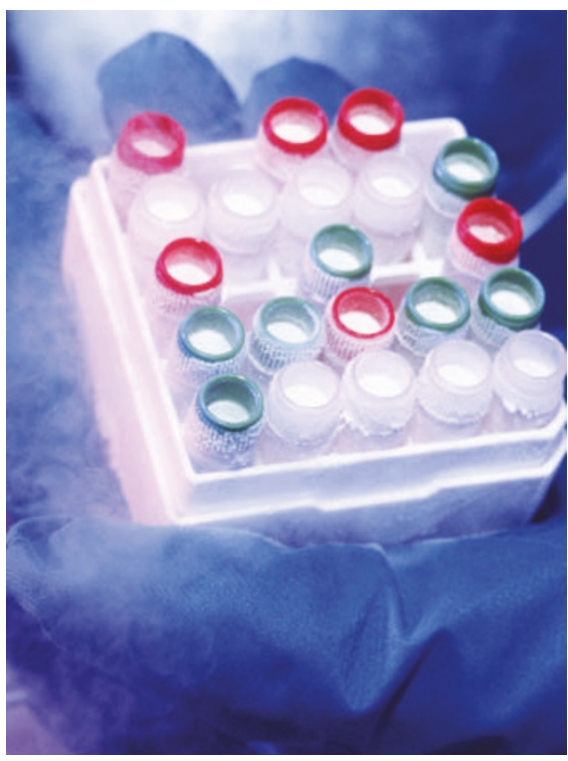

Bright idea: derivation of extra stem-cell lines builds pressure on President Bush's restrictions.

has access to a unique patient population, because the institute runs a large preimplantation diagnosis programme. This means that couples attending the clinic for assisted-reproduction services can have their embryos screened for genetic diseases before they are implanted in the mother's womb. If the screening turns up disease genes, says Kuliev, stem cells are collected from the embryos, with the couple's consent, and propagated into stable lines.

"Our emphasis is on establishing embryonic stem cells with different genetic abnormalities," Kuliev adds.

"I think this is highly significant," says George Daley, a cell biologist at the Children's Hospital in Boston. "This is a large number of new lines, many representing models of human disease."

Kuliev says that his group will make the newly created lines available to other researchers, although the terms of these collaborations are still to be worked out.

No scientist using federal funding will be able to use the cells, because President Bush's ruling of 9 August 2001 bars them from using lines created after that date.

This policy has been coming under pressure lately. On 4 June, 58 senators sent a letter to President Bush asking him to revisit it. And on 12 June, Senator John Kerry (Democrat, Massachusetts), who is his opponent in this November's election, took up the issue as part of his campaign.

\section{Alcohol report directs drinkers to their doctors}

Helen Pearson, New York

A drink a day keeps the doctor away from some of us, concludes a review by the National Institute on Alcohol Abuse and Alcoholism (NIAAA) in the United States. But you need to ask your doctor if your level of drinking is healthy, it adds.

Many people assume that a tipple or two a day is a tonic, but researchers believe this assumption is based chiefly on misleading media reports and wishful thinking. The institute reviewed scientific literature showing the relative risks and benefits of drinking in moderation (L. Gunzerath, V. Faden, S. Zakhari \& K. Warren Alcohol. Clin. Exp. Res. 28, 829-847; 2004).

Rather than producing an easy rule of thumb, the review concludes that the healthiest level of consumption depends on an individual's age, sex, overall health and lifestyle - a calculation best totted up in the doctor's office. "We cannot give a blanket statement that alcohol is good for you so go out and enjoy," says the institute's Samir Zakhari, one of the authors of the report.

The case for alcohol is based on findings that moderate drinkers are at lower risk of heart disease than either abstainers or heavy imbibers. The review weighs these benefits

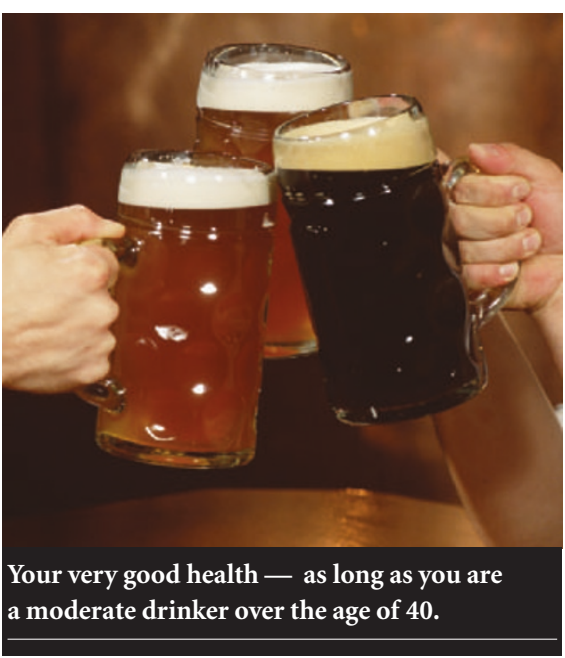

against alcohol's myriad detrimental effects, such as the increased risk of injury, breast cancer, liver disease and other conditions.

When both benefits and risks are factored into the equation, the reviewers conclude, people still seem to reduce their overall health risks by having one or two alcoholic drinks a day. But the degree of benefit varies from person to person, says Zakhari. People aged 40 or more, who are already under some threat from heart disease, seem to benefit the most, whereas younger drinkers may gain very little.

The NIAAA review adds that there is little consensus among experts about what constitutes 'moderate' drinking. Some studies consider this to be one drink a week, others as many as four a day.

The review's contents are likely to provide the basis for the alcohol section of new dietary advice due to be released by the US government next year.

Despite its complicated conclusions, experts welcomed the attempt to weigh up the pros and cons of moderate drinking. "It's as good as it could have been," says Kenneth Mukamal, who studies alcohol and health at Harvard Medical School, Boston.

But some researchers doubt that the report's contents, and other reliable advice on healthy drinking, are reaching those already at the bar (see Nature 428, 598-600; 2004). Rather than disseminating a vague notion of moderation, drinks labels and trained bar staff should advise people not to exceed one or two drinks a day, suggests alcohol-policy expert Thomas Babor at the University of Connecticut, Farmington. "It's now a question of getting the message out there," he says. 